\title{
FAKTOR-FAKTOR YANG MEMPENGARUHI PERKEMBANGAN USAHA KECIL SEKTOR INDUSTRI PENGOLAHAN DI KOTA MALANG
}

\author{
Mega Mirasaputri Cahyanti \\ Widiya Dewi Anjaningrum \\ Dosen STIE ASIA Malang
}

\begin{abstract}
This study aims to determine the factors that influence the development of the small business manufacturing sector in Malang town. This research is a kind of field research, where the primary quantitative data through questionnaire was taken directly from small businesses. The sampling technique that was used is purposive sampling, where the sample was selected based on the consideration which the sample could provide some informations that are suitable with the needs of the research. Based on the Slovin formula, a predetermine number of samples that taken was 89 small businesses. Based on the result taken by data processing and factor analysis using SPSS 23, shows that the factors which influence the development of small business manufacturing sector are the quality of human resources, production systems, financial management systems, marketing strategies, the partnership system, the quality of infrastructure and regulation. In this case, the factor which has the higest significant effect is partnership system. Finally, improving the partnership system on small business should be developed not only with suppliers, but also with the government, large business, financial institutions and business centers. Therefore, these small business could be thrive.

Key Words: small business development, manufacturing, human resource quality, production system, financial management system, marketing strategies, partnership system, infrastructure and regulation quality.
\end{abstract}

\begin{abstract}
ABSTRAKSI
Penelitian ini bertujuan untuk mengetahui faktor-faktor apa saja yang mempengaruhi perkembangan usaha kecil sektor industri pengolahan di kota Malang. Penelitian ini merupakan field research, di mana data primer kuantitatif melalui instrumen berupa kuisioner diambil secara langsung dari pelaku usaha kecil. Teknik yang sampling yang digunakan adalah purposive sampling di mana sampel dipilih berdasarkan pertimbangan bahwa sampel yang terpilih dapat memberikan informasi yang sesuai dengan kebutuhan penelitian. Berdasarkan rumus Slovin, ditentukan jumlah sampel yang diambil sebanyak 89 usaha kecil. Adapun hasil olah data dan analisis faktor dengan menggunakan SPSS 23 menunjukkan bahwa faktor-faktor yang mempengaruhi perkembangan usaha kecil sektor industri pengolahan antara lain: kualitas sumber daya manusia, sistem produksi, sistem pengelolaan keuangan, strategi pemasaran, sistem kemitraan serta kualitas infrastruktur dan regulasi. Faktor berpengaruh positif dan signifikan adalah sistem kemitraan. Peningkatan sistem kemitraan, baik kemitraan dengan pemasok, pemerintah, pengusaha besar, lembaga keuangan maupun sentra dapat mend ukung faktor-faktor lainnya, sedemikian hingga industri pengolahan dapat berkembang pesat.

Kata Kunci: Perkembangan Industri Kecil, Industri Pengolahan, Kualitas Sumber Daya Manusia, Sistem Produksi, Sistem Pengelolaan Keuangan, Strategi Pemasaran, Sistem Kemitraan, Kualitas Infrastruktur dan Regulasi
\end{abstract}

\section{PENDAHULUAN}

Usaha kecil berperan sebagai kekuatan strategis dan memiliki posisi penting, tidak hanya dalam hal penyerapan tenaga kerja dan kesejahteraan masyarakat, tetapi juga untuk menstabilkan masalah kesenjangan sosial. Produk yang dihasilkan usaha kecil umumnya juga berbasis pada kebutuhan masyarakat luas dan memiliki keunggulan yang komparatif. Selain itu, usaha kecil yang memiliki faktorfaktor produksi tidak bergantung pada valuta asing, lebih dapat bertahan dari krisis daripada usaha besar. Sehingga, perkembangan usaha kecil merupakan hal penting untuk ditinjau lebih dalam. Terdapat beberapa sektor dalam usaha kecil, antara lain: sektor industri pengolahan, jasa-jasa, keuangan, konstruksi, perdagangan, hotel dan restoran, pertanian dan transportasi. Salah satu sektor yang memberikan kontribusi tinggi terhadap PDRB (Produk Domestik Regional Bruto) kota Malang adalah sektor industri pengolahan, yaitu mencapai 33\% (BPS Kota Malang, 2013). Ini menunjukkan bahwa sektor industri pengolahan potensial meningkatkan PDRB dan representatif dalam memberdayakan ekonomi masyarakat kota Malang, sehingga penting untuk dikembangkan. Namun, untuk mencapai perkembangan yang pesat, usaha kecil menghadapi komplikasi hambatan, seperti: keterbatasan 
modal, sumber daya yang kurang berkualitas, sistem produksi yang kurang efisien, tidak adanya sistem pengelolaan keuangan, strategi pemasaran yang kurang jitu, minimnya teknologi yang digunakan, infrastruktur yang kurang mendukung, regulasi yang tidak jelas, dan lain sebagainya. Oleh karena itu, dalam penelitian ini dibahas faktor-faktor apa saja yang berpengaruh terhadap perkembangan usaha kecil sektor industri pengolahan yang ada di kota Malang. Sedemikian hingga, hasil penelitian ini dapat digunakan oleh pelaku usaha untuk mendobrak daya yang dimiliki demi tercapainya perkembangan usaha yang signifikan, juga dapat digunakan oleh pemerintah untuk dijadikan salah satu dasar pengambilan kebijakan dan peraturan yang lebih mendukung perkembangan usaha kecil di kota Malang.

\section{LANDASAN TEORI \\ Usaha Kecil}

Berdasarkan Undang-Undang Nomor

20 Tahun 2008 tentang Usaha Mikro, Kecil dan Menengah (UMKM), Usaha Kecil adalah usaha ekonomi produktif yang berdiri sendiri, yang dilakukan oleh orang perorangan atau badan usaha yang bukan merupakan anak perusahaan atau bukan cabang perusahaan yang dimiliki, dikuasai, atau menjadi bagian baik langsung maupun tak langsung dari Usaha Menengah atau Usaha Besar yang memiliki modal sebesar Rp 50 juta sampai dengan Rp 500 juta. Menurut Sutrisno dan Lestari (2006), berdasarkan perkembangan usaha, Usaha Kecil Menengah dikelompokkan ke dalam beberapa kriteria, yaitu: (1) Livelihood Activities, merupakan Usaha Kecil Menengah yang digunakan sebagai kesempatan kerja untuk emncari nafkah, yang lebih umum dikenal sebagai sektor informal seperti pedagang kaki lima; (2) Micro Enterprise merupakan Usaha Kecil Menengah yang memiliki sifat pengrajin tetapi belum memiliki sifat kewirausahaan; (3) Small Dynamic Enterprise merupakan Usaha Kecil Menengah yang telah memiliki jiwa kewirausaah dan mampu menerima pekerjaan subkontrak dan ekspor; (4) Fast Moving Enterprise merupakan Usaha Kecil Menengah yang telah memiliki jiwa kewirausahaan dan akan melakukan trasformasi menjadi Usaha Besar.

\section{Industri Pengolahan}

Industri Pengolahan adalah suatu kegiatan ekonomi yang melakukan kegiatan mengubah suatu barang dasar secara mekanis, kimia, atau dengan tangan sehingga menjadi barang jadi atau setengah jadi, dan atau barang yang kurang nilainya menjadi barang yang lebih tinggi nilainya, dan sifatnya lebih dekat kepada pemakai akhir (BPS, 2017).

\section{Perkembangan Usaha}

Menurut Bappeda Kota Malang (2015), ada 6 aspek yang mempengaruhi perkembangan Usaha Kecil yaitu: sumber daya manusia, produksi/operasional, finansial, pemasaran, kemitraan, infrastruktur dan regulasi. Sementara menurut Madura (2001), perkembangan usaha dapat diukur melalui kinerja usaha dengan indikator return dan risiko dari penanaman modal ke usaha tersebut. Sedangkan menurut Shanmugam dan Bhaduri (2002), perkembangan usaha kecil dapat dilihat melalui pertumbuhan produksi, pertumbuhan penjualan, pertumbuhan pendapatan dan pertumbuhan laba.

Hasil penelitian Susanty, dkk (2013) menunjukkan bahwa faktor-faktor yang mempengaruhi pertumbuhan klaster batik pekalongan yaitu keberadaan industri pendukung dan terkait, strategi dan persaingan usaha, serta peran dari pemerintah. Sedangkan penelitian Purba (2010) menunjukkan bahwa kredit UKM, kemudian pengangguran dan upah berpengaruh positif dan signifikan terhadap perkembangan pertumbuhan industri kecil, sedangkan penanaman modal dalam negeri berpengaruh positif tetapi tidak signifikan terhadap perkembangan pertumbuhan industri kecil. Kristiningsih dan Trimarjono (2014), menyatakan bahwa perkembangan usaha dapat diukur melalui keberhasilan usaha tersebut yang dicerminkan oleh kinerja usaha. Adapun kinerja yang dimaksudkan adalah tingkat pencapaian hasil atau tingkat pencapaian tujuan organisasi (Sumarmi dan Soeprihanto, 1998). Penilitian Indriyatni (2013) menunjukkan bahwa faktor Modal Kerja, kemampuan/skill, dan lokasi usaha berpengaruh positif dan signifikan terhadap keberhasilan usaha mikro kecil.

\section{Kualitas Sumber Daya manusia}

Menurut Joesron (2005), kualitas sumber daya manusia adalah potensi, kekuatan, atau kemampuan yang ada dalam diri manusia yang menentukan sikap dan kualitas manusia untuk dapat berprestasi dan menjadikan organisasinya tetap hidup dan berjalan. Sedangkan menurut Soekidjo (2003), kualitas sumber daya manusia meliputi aspek fisik dan non fisik yang menyangkut kemampuan bekerja, berpikir dan ketrampilan. Kasanudin (2011) mengukur kualitas sumber daya manusia berdasarkan produktivitas, sikap dan perilaku, komunikasi, dan relationship.

\section{Sistem Produksi}

Sistem produksi merupakan kumpulan dari sub sistem yang saling berinteraksi dengan tujuan mentransformasi input produksi menjadi output produksi. Input produksi ini dapat berupa bahan baku, mesin, tenaga kerja, modal dan 
informasi. Sedangkan output produksi merupakan produk yang dihasilkan berikut sampingannya seperti limbah, informasi, dan sebagainya (Ginting, 2007).

\section{Sistem Pengelolaan Keuangan}

Pengertian sistem pengelolaan keuangan menurut Baridwan (2008) adalah suatu kerangka dari prosedur-prosedur yang saling berhubungan yang disusun sesuai dengan suatu skema yang menyeluruh, untuk melaksanakan kegiatan yang meliputi perencanaan, pelaksanaan, penatausahaan, pelaporan, pertanggung-jawaban, dan pengawasan keuangan.

\section{Strategi Pemasaran}

Menurut Tull dan Kahle (1990) dalam Tjiptono (2004), Strategi pemasaran penting untuk membantu meningkatkan daya saing perusahaan dalam menghadapi era globalisasi dan liberalisasi. Strategi pemasaran merupakan alat fundamental yang direncanakan untuk mencapai tujuan perusahaan dengan mengembangkan keunggulan bersaing yang berkesinambungan. Sedemikian hingga, strategi pemasaran yang digunakan dapat memandu para manajer ataupun pemilik perusahaan dalam melakukan taktik dan kegiatan lainnya untuk meningkatkan tujuan perusahaan.

\section{Sistem Kemitraan}

Kemitraan Usaha adalah jalinan kerjasama usaha yang saling menguntungkan antara pengusaha kecil dengan pengusaha menengah/besar (Perusahaan Mitra) disertai dengan pembinaan dan pengembangan oleh pengusaha besar, sehingga saling memerlukan, menguntungkan dan memperkuat (Liptan, 2000). Sedangkan menurut Peraturan Pemerintah Republik Indonesia No.44 tahun 1997, kemitraan adalah kerjasama usaha antara Usaha Kecil dengan Usaha Menengah dan atau dengan Usaha Besar disertai pembinaan dan pengembangan oleh Usaha Menengah dan atau Usaha Besar dengan memperhatikan prinsip saling memerlukan, saling memperkuat dan saling menguntungkan. Untuk perkembangan usaha kecil yang signifikan diperlukan kemitraan antara usaha kecil, pemasok, pemerintah, pengusaha, lembaga keuangan dan sentra (Bappeda Kota Malang, 2015).

\section{Kualitas Infrastruktur dan Regulasi}

Usaha Kecil membutuhkan pelindung berupa kebijakan pemerintah seperti undangundang dan peraturan pemerintah. Regulasi merupakan seperangkat aturan yang dimaksudkan untuk memberikan perlindungan dan manfaat untuk masyarakat pada umumnya atau pada sekelompok masyarakat. Selain regulasi, pemerintah dapat mendukung perkembangan usaha kecil melalui perbaikan infrastruktur. Merujuk pada publikasi World
Development Report (World Bank, 1994), infrastruktur berperan penting dalam meningkatkan pertumbuhan ekonomi di mana pertumbuhan ekonomi yang lebih tinggi dijumpai pada wilayah dengan tingkat ketersediaan infrastruktur yang mencukupi. Identifikasi terhadap program pembangunan infrastruktur di beberapa negara menyimpulkan bahwa pada umumnya program ditargetkan dalam jangka menengah dengan fokus pada peningkatan kebutuhan dasar dan konektivitas manusia, mulai dari air, listrik, energi, hingga transportasi (jalan raya, kereta api, pelabuhan, dan bandara).

\section{KERANGKA KONSEPTUAL DAN HIPOTESIS}

Berikut ini adalah gambar bagan kerangka konseptual penelitian ini, di mana diduga ada 6 faktor utama yang mempengaruhi perkembangan usaha kecil sektor industri pengolahan di Kota Malang.

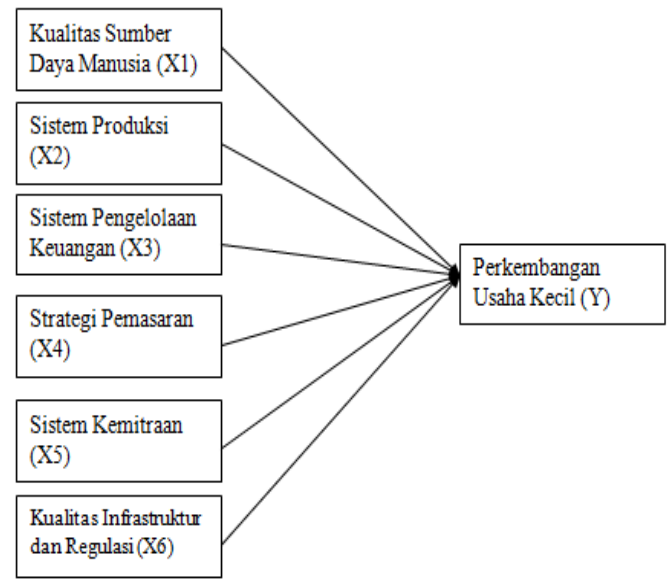

Adapun hipotesis-hipotesis yang diambil dalam penelitian ini antara lain:

H1: Kualitas sumber daya manusia merupakan salah satu faktor yang mempengaruhi perkembangan usaha kecil sektor industri pengolahan di Kota Malang

H2: Sistem Produksi merupakan salah satu faktor yang mempengaruhi perkembangan usaha kecil sektor industri pengolahan di Kota Malang

H3: Sistem pengelolaan keuangan merupakan salah satu faktor yang mempengaruhi perkembangan usaha kecil sektor industri pengolahan di Kota Malang

H4: Strategi Pemasaran merupakan salah satu faktor yang mempengaruhi perkembangan usaha kecil sektor industri pengolahan di Kota Malang

H5: Sistem Kemitraan merupakan salah satu faktor yang mempengaruhi perkembangan usaha kecil sektor industri pengolahan di Kota Malang 
H6: Kualitas Infrastruktur dan Regulasi merupakan salah satu faktor yang mempengaruhi perkembangan usaha kecil sektor industri pengolahan di Kota Malang

\section{METODE PENELITIAN}

Jenis Penelitian, Populasi, Teknik Sampling dan Sampel Penelitian

Penelitian ini merupakan field research, di mana data primer kuantitatif melalui instrumen berupa kuisioner diambil secara langsung dari lapangan (masyarakat pelaku usaha kecil sektor industri di Kota Malang). Adapun populasi Usaha Kecil Industri Pengolahan di Kota Malang disajikan dalam Tabel 1. berikut.

Tabel 1. Populasi Usaha Kecil Sektor Industri Pengolahan di Kota malang

\begin{tabular}{|l|l|}
\hline KECAMATAN & JUMLAH \\
\hline Blimbing & 217 \\
\hline Kedungkandang & 171 \\
\hline Klojen & 107 \\
\hline Lowokwaru & 110 \\
\hline Sukun & 172 \\
\hline Total & $\mathbf{7 7 7}$ \\
\hline
\end{tabular}

Sumber: (Bappeda, 2014)

Teknik sampling yang digunakan dalam penelitian ini adalah purposive sampling yang merupakan bagian dari non-probability sampling, di mana sampel dipilih berdasarkan pertimbangan bahwa sampel yang terpilih dapat menjawab atau memberikan informasi yang sesuai dengan kebutuhan penelitian. Sedangkan jumlah sampel minimal yang dibutuhkan dalam penelitian dengan tingkat kepercayaan $90 \%$ atau $\alpha=0,1$ dihitung dengan rumus Slovin sebagai berikut:

$$
n=\frac{N}{1+N \alpha^{2}}=\frac{777}{1+777 \cdot 0,1^{2}}=88,597
$$

Sedemikian hingga jumlah usaha kecil sektor industri pengolahan yang diteliti sebanyak 89 usaha kecil.

Definisi Operasional Variabel dan Metode

Pengukuran

Variabel Independent

\section{X1: Kualitas Sumber Daya Manusia}

X1.1: Kualitas Pengusaha

X1.1.1: Inisiatif Pengusaha Mengembangkan Usaha (Skala Likert 1 - 5)

X1.1.2: Tingkat Pendidikan Pengusaha (Skala Ordinal 1.SD 2.SMP 3.SMA 4.S1 5.S2)

X1.1.3: Pengetahuan Informasi Pengusaha tentang Regulasi dan Agenda Pemerintah (Skala Likert 1 - 5)

X1.1.4: Pengetahuan Pengusaha akan Perkembangan Teknologi (Skala Likert 1-5)

X1.2: Kualitas Pekerja

X1.2.1: Motivasi Pekerja (Skala Likert 1-5)
X1.2.2: Kedisiplinan Pekerja (Skala Likert 1 5)

X1.2.3: Tingkat Kompetensi antar Pekerja (Skala Likert 1 - 5)

X1.2.4: Tingkat Pendidikan Pekerja (Skala Ordinal 1.SD 2.SMP 3.SMA 4.S1 5.S2 )

X1.2.5: Frekuensi Pelatihan (Skala Likert 1-5)

X1.2.6: Kepuasan Adanya Jaminan Sosial (Skala Likert 1 - 5)

X1.3 Ketepatan Struktur Organisasi dan Efektifias Struktural (Skala Likert 1-5)

$\mathrm{X} 2$ : Sis tem produksi

X2.1: Ketersediaan Bahan Baku (Skala Likert 1 $-5)$

X2.2: Harga Bahan Baku (Skala Likert 1-5)

X2.3: Efisiensi Proses Produksi (Sakala Likert 1 $-5)$

X2.4: Quality Control (Skala Likert 1-5)

X2.5: Tingkat Teknologi yang digunakan (Skala Likert 1-5)

X3: Sistem pengelolaan keuangan

X3.1: Kecukupan Modal (Skala Likert 1-5)

X3.2: Kemudahan Akses Permodalan (Skala Likert 1-5)

X3.3: Biaya Transaksi Perolehan Modal (Skala Likert 1-5)

X3.4: Bunga Kredit Investasi (Skala Likert 1 5)

X3.5: Kualitas Pembukuan/Akuntansi (Skala Likert 1 - 5)

X3.6: Kualitas Penggunaan Bank (Skala Likert $1-5)$

X4: Strategi pemasaran

X4.1: Kualitas Sistem Pemasaran (Skala Likert $1-5)$

X4.2: Jangkauan Area Pemasaran (Skala Ordinal 1.Kecamatan 2.Kota 3.Provinsi 4.Nasional 5.Internasional)

X4.3: Ketepatan Segmentasi Pasar (Skala Likert $1-5)$

X4.4: Intensitas Penggunaan Media

Cetak/Elektronika (Skala Likert 1-5)

X4.5: Intensitas Penggunaan Internet/Online Marketing (Skala Likert 1 - 5)

X4.6: Ketepatan Strategi Pemasaran (Skala Likert 1-5)

\section{X5: Sistem kemitraan}

X5.1: Efektifitas Sistem kemitraan dengan Pemasok (Skala Likert 1 - 5)

X5.2: Efektifitas Sistem kemitraan dengan Pengusaha Sejenis (Sentra) (Skala Likert 1-5)

X5.3: Efektifitas Sistem Linkage dengan Perusahaan Besar, Perguruan Tinggi dan Pemerintah (Skala Likert 1-5)

X6: Kualitas Infrastruktur dan Regulasi

X6.1: Akses Transportasi dan Telekomunikasi (Skala Likert 1 - 5)

X6.2: Ketersediaan Listrik dan Air (Skala Likert $1-5)$ 
X6.3: Information Center UMKM (Skala Likert $1-5)$

X6.4: Peran Lembaga Incubator UMKM (Skala Likert 1-5)

X6.5: Manfaat Pelatihan dan Pembinaan Langsung dari Pemerintah (Skala Likert 1-5)

X6.6: Kualitas Proses Perizinan (Skala Likert 1 $-5)$

X6.7: Pajak dan Pungutan Liar (Skala Likert 1 5)

X6.8: Manfaat Regulasi Pemerintah (Skala

Likert 1-5)

X6.9: Akses informasi regulasi dan agenda pemerintah (Skala Likert 1-5)

Variabel Dependent

Y: Perkembangan Usaha 5 tahun terkhir

Y1: Persentase Peningkatan Produksi (Skala Ordinal)

Y2: Persentase Peningkatan Volume Penjualan atau Omzet (Skala Ordinal)

Y3: Persentase Peningkatan Jumlah Karyawan (Skala Ordinal)

Y4: Persentase Peningkatan Laba (Skala Ordinal)

\section{Pemenuhan Asumsi dan Analisis Faktor}

Sebelum melakukan analisis faktor, ada beberapa asumsi yang harus dipenuhi antara lain: instrumen penelitian valid, data dari jawaban responden reliabel, data berdistribusi normal, tidak terjadi multikolinearitas dan tidak terjadi heteroskedastisitas. Analisis faktor dilakukan dengan melakukan regresi semua faktor yang telah ditentukan (variabel independent) terhadap perkembangan usaha kecil (variabel dependent). Selanjutnya dilakukan uji determinasi (R-Square) dan uji F untuk menunjukkan apakah semua variabel independent tersebut merupakan faktor-faktor yang mempengaruhi perkembangan usaha kecil atau tidak. Jika memang terbukti merupakan faktor-faktor yang mempengaruhi perkembangan usaha kecil, selanjutnya dibentuk model regresi linier berganda, kemudian dilakukan uji t untuk mengetahui faktor-faktor mana yang memiliki pengaruh signifikan terhadap perkembangan usaha kecil.

\section{HASIL DAN PEMBAHASAN \\ Pemenuhan Asumsi}

Sebanyak 89 data hasil kuisioner dari sampel yang dipilih dalam penelitian ini telah memenuhi uji validitas dan reliabilitas dengan dihasilkannya Sig. (2-tailed) ketujuh variabel (baik variabel independent maupun dependent) terhadap variabel total sebesar 0,000 yang lebih kecil dari 0,1 (taraf signifikansi 10\%) dan nilai Cronbach's Alpha sebesar 0,975 yang lebih besar dari 0,6. Demikian juga pemenuhan asumsi klasik yang meliputi normalitas, multikolinearitas dan heteroskedastisitas. Nilai
Sig. Kolmogorov-Smirnov output SPSS variabel Kualitas SDM, Produksi/Operasional, Pengelolaan Keuangan dan Pemasaran sebesar 0,200; variabel Sistem kemitraan 0,073; variabel Kualitas Infrastruktur dan Regulasi 0,097 dan variabel Perkembangan Usaha 0,069 lebih besar dari 0,1 (taraf signifikansi 10\%). Artinya, semua data variabel berdistribusi normal. Nilai VIF semua variabel independent dalam Tabel Coefficients output SPSS juga kurang dari 10 yang berarti tidak terjadi multikolinearitas. Scatterplot output SPSS juga tidak menunjukkan pola tertentu sehingga tidak terjadi heteroskedastisitas. Karena data berdistribusi normal, tidak terjadi multikolinearitas dan heteroskedastisitas, maka data ini telah memenuhi kaidah BLUE (Best Linear Unbiased Estimator).

Analisis Faktor Koefisien Determinasi

Model Summary

\begin{tabular}{|c|c|c|c|c|c|}
\hline Model & $R$ & R Square & $\begin{array}{l}\text { Adjusted } \\
R \text { Square }\end{array}$ & $\begin{array}{l}\text { Std. Error of } \\
\text { the Estimate }\end{array}$ & $\begin{array}{l}\text { Durbin- } \\
\text { Watson }\end{array}$ \\
\hline 1 & $920^{3}$ & 846 & 835 & 9,930 & 2,510 \\
\hline \multicolumn{6}{|c|}{$\begin{array}{l}\text { a. Predictors: (Constant), Kualitas Infrastruktur dan Regulasi, } \\
\text { Sistem pengelolaan keuangan, Strategi pemasaran, Sistem } \\
\text { kemitraan, Kualitas SDM, Sistem produksi } \\
\text { b. Dependent Variable: Perkembangan Usaha }\end{array}$} \\
\hline
\end{tabular}

Berdasarkan Tabel Model Summary output SPSS di atas diketahui bahwa koefisien determinasi ( $R$ Square) yang berfungsi untuk melihat sejauh mana keseluruhan variabel independent dapat menjelaskan variabel dependent sebesar 0,846. Artinya, 84,6\% perkembangan usaha kecil sektor industri pengolahan di kota Malang dijelaskan oleh kualitas sumber daya manusia, produksi/operasional, pengelolaan keuangan, pemasaran, kemitraan, infrastruktur dan regulasi. Sedangkan sisanya, sebesar $100 \%-84,6 \%=15,4 \%$ dijelaskan oleh variabel-variabel lain yang tidak dipertimbangkan dalam penelitian ini. Dengan kata lain, keenam variabel independent, yaitu, kualitas SDM, sistem produksi, sistem pengelolaan keuangan, strategi pemasaran, sistem kemitraan dan kualitas infrastuktur dan regulasi merupakan faktor-faktor yang mempengaruhi perkembangan usaha kecil sektor industri pengolahan di Kota Malang.

\section{Uji F}




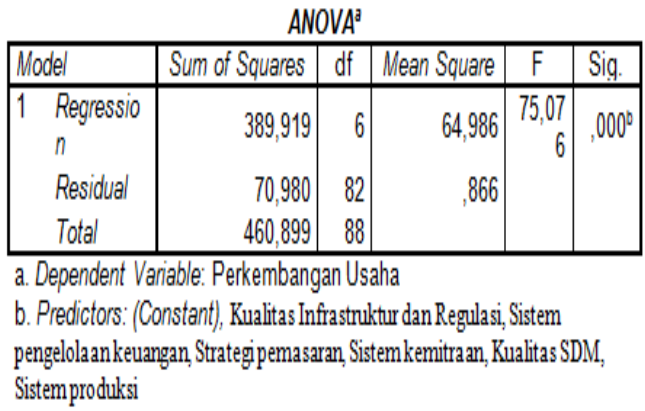

Berdasarkan Tabel ANOVA di atas, ditunjukkan bahwa nilai F-hitung sebesar 75,076 lebih besar dari F-Tabel sebesar 1,847251, demikian juga nilai Sig. dari F-hitung sebesar 0,000 lebih kecil dari 0,1 (taraf signifikansi yang diambil), artinya, bahwa model regresi yang akan dibentuk memenuhi goodness of fit model atau model regresi yang dibentuk dapat memprediksi perkembangan usaha kecil sektor industri pengolahan di kota Malang. Dengan kata lain, Sehingga, semua hipotesis terbukti kebenarannya, atau H1, H2, H3, H4, H5 dan H6 diterima.

\section{Model Regresi Linier Berganda}

\begin{tabular}{|c|c|c|c|c|c|}
\hline \multicolumn{6}{|c|}{ Coefficients ${ }^{a}$} \\
\hline \multirow[b]{2}{*}{ Model } & \multicolumn{2}{|c|}{$\begin{array}{l}\text { Unstandardized } \\
\text { Coefficients }\end{array}$} & \multirow{2}{*}{$\begin{array}{c}\begin{array}{c}\text { Standardize } \\
d \\
\text { Coefficients }\end{array} \\
\text { Beta }\end{array}$} & \multirow[b]{2}{*}{$t$} & \multirow[b]{2}{*}{ Sig. } \\
\hline & B & $\begin{array}{l}\text { Std. } \\
\text { Error }\end{array}$ & & & \\
\hline $\begin{array}{ll}1 & \text { (Constant) } \\
\end{array}$ & $-2,071$ & 1,301 & & $-1,593$ & .115 \\
\hline Kualitas SDM &, 075 & 078 & ,114 &, 954 &, 343 \\
\hline Sistem produksi & 240 & 108 & 285 & 2,222 & .029 \\
\hline Sistem pengelolaan keuangan & 021 &, 075 &, 027 & 275 &, 784 \\
\hline Strategi pemasaran & 105 & 077 & ,143 & 1,362 & 177 \\
\hline Sistem kemitraan & 322 & 107 & ,338 & 3,002 & ,004 \\
\hline $\begin{array}{l}\text { Kualitas Infrastruktur dan } \\
\text { Regulasi }\end{array}$ &, 072 & 084 & 109 & 851 & 397 \\
\hline
\end{tabular}

Berdasarkan nilai B dalam Tabel Coefficients output SPSS di atas dapat dibentuk Model Regresi Linier Berganda sebagai berikut: $Y=-2,071+0,075 X_{1}+0,240 X_{2}+0,021 X_{3}+0,105 X_{4}+0,322 X_{5}+0,072 X_{6}$

\section{Uji t}

Sedangkan berdasarkan nilai t dalam Tabel Coefficients di atas diketahui bahwa hanya t-hitung dari variabel sistem kemitraan yang berada di dalam rentang \pm t-tabel sebesar 1,663649 pada taraf signifikansi 10\%. Artinya, pada tingkat kepercayaan 90\%, hanya variabel sistem kemitraan yang berpengaruh positif dan signifikan terhadap perkembangan usaha kecil sektor industri pengolahan di kota Malang, sedangkan variabel kualitas sumber daya manusia, sistem produksi, sistem pengelolaan keuangan, strategi pemasaran, kualitas infrastruktur dan regulasi berpengaruh positif tetapi tidak signifikan. Sehingga, untuk mempercepat perkembangan usaha kecil khususnya sektor industri pengolahan di kota
Malang, maka yang harus diprioritaskan adalah sistem kemitraan.

Sistem kemitraan yang tinggi, baik kemitraan dengan para pemasok bahan baku, pemerintah, lembaga keuangan, sentra, pengusaha yang lebih besar dan perguruan tinggi maupun lembaga inkubator khusus, sangat menguntungkan usaha kecil. Langkah kerjasama dalam bentuk kemitraan merupakan salah satu strategi jitu untuk mengembangkan usaha kecil. Jika sistem kemitraan tinggi, maka dapat mendukung faktor-faktor lainnya, sehingga secara otomatis perkembangan usaha kecil dapat meningkat dengan pesat.

Sistem kemitraan yang tinggi dengan lembaga keuangan dapat memudahkan usaha kecil memperoleh modal usaha. Didukung dengan kemitraan yang kondusif dengan pemasok dapat mengefisiensikan biaya produksi, karena melalui kemitraan tersebut, usaha kecil dapat memperoleh bahan baku dengan harga yang lebih murah dengan kualitas sesuai harapan. Usaha kecil juga akan memperoleh pelatihan dan pembinaan terkait manajemen dan IPTEK dari hasil kemitraan dengan perguruan tinggi dan lembaga inkubator. Sementara kemitraan dengan sentra atau usaha kecil sejenis dapat mencapai lindung nilai akan produk mereka untuk menghadapi pesaing dari luar kota, juga dapat digunakan untuk distribusi produksi jika ada usaha kecil yang mendapatkan order melebihi kapasitas. Sedangkan kemitraan dengan pemerintah, selain mendapatkan kemudahan dalam proses perizinan, usaha kecil juga akan mendapatkan pelatihan dan pembinaan langsung, mendapatkan bantuan pemasaran melalui berbagai program yang diadakan oleh pemerintah, juga mendapatkan imbas dari pembenahan infrastruktur dan perlindungan hukum melalui berbagai regulasi. Kemitraan yang kuat dapat meningkatkan bargaining position yang menguntungkan, mencegah pembentukan struktur pasar yang mengarah terjadinya persaingan tidak sehat dalam bentuk monopoli, oligopoli dan monopsoni, juga mencegah terjadinya penguasaan pasar dan pemusatan usaha oleh orang perseorangan atau kelompok tertentu yang merugikan usaha kecil.

\section{SIMPULAN DAN SARAN}

Berdasarkan analisis faktor yang dilakukan dapat ditarik kesimpulan bahwa faktor-faktor yang mempengaruhi perkembangan usaha kecil sektor industri pengolahan di Kota Malang antara lain: kualitas sumber daya manusia, sistem produksi, sistem pengelolaan keuangan, strategi pemasaran, sistem kemitraan serta kualitas infrastruktur dan regulasi. Faktor yang berpengaruh positif dan 
signifikan terhadap perkembangan usaha kecil adalah sistem kemitraan. Oleh karena itu, disarankan agar usaha kecil khususnya sektor industri pengolahan yang berada di kota Malang berinisiatif untuk meningkatkan kemitraan, baik kemitraan dengan pemasok, pemerintah, perguruan tinggi, lembaga inkubator, lembaga keuangan, usaha besar maupun usaha kecil sejenis (sentra).

\section{DAFTAR PUSTAKA}

1. Bappeda Kota Malang, 2015, Naskah Akademik dan Rancangan Peraturan Daerah Kota Malang tentang Pemberdayaan Usaha Mikro Kecil dan Menengah, Bappeda, Malang.

2. Baridwan, Zaki. 2008. Intermediate Accounting. Edisi Kedelapan. BPFE. Yogyakarta.

3. BPS Kota Malang, 2013, Produk Domestik Bruto, diunduh dari: http://www.bps.go.id/index.php?news =730, diaks es pada tanggal 5 Oktober 2016.

4. BPS, 2017, Industri Pengolahan, diunduh dari: https://www.bps.go.id/Subjek/vew/ide/9, diakses pada tanggal 22 Januari 2017.

5. Indriyatni, Lies, 2013, Analisis FaktorFaktoryang Berpengaruh terhadap Keberhasilan Usaha mikro dan Kecil, Jurnal STIE Semarang, Vol.5, No.1, Hal:54-70.

6. Kasanudin, Mukhamad, 2011, Pengaruh Kualitas Sumber Daya Manusia (SDM) Pengelola Koperasi terhadap Kinerja Koperasi Pondok Pesantren di Kabupaten Demak, Skripsi, Isntitute Agama Islam Negeri Walisongo, Semarang.

7. Kristiningsih dan Adrianto Trimarjono, 2014, Analisis Faktor-Faktoryang Mempengaruhi Perkembangan Usaha Kecil Menengah (Studi Kasus pada UKM di Wilayah Surabaya), The 7th NCFB Doctoral Colloquium 2014, Fakultas Bisnis dan Pascasarjana Universitas Wijaya Kusuma, Surabaya.

8. Liptan, 2000, Kemitraan Usaha, Loka Pengkajian Teknologi Pertanian Koya Barat, Sentani, Jayapura.

9. Madura, Jeff, 2001, Pengantar Bisnis, Jilid I, Salemba Empat, Jakarta.

10. Peraturan Pemerintah Republik Indonesia Nomor 44 tahun 1997 tentang Kemitraan, Pemerintah Republik Indonesia, Jakarta.

11. Purba, Abdillah Harja, 2010, Analisis Faktor-faktoryang Mempengaruhi Pertumbuhan Industri Kecil di Kota Medan, Tesis, Sekolah Pascasarjana Universitas Sumatera Utara, Medan.

12. Shanmugam, K. R., dan Bhaduri, S. N., 2002, Size, Age, and Firm Growth in the
Indian Manufacturing Sector, Applied Economics Letters, 9, pp: 607-613.

13. Susanty, Aries, Naniek Utami Handayani, dan Prima Andidya Jati, 2013, Analisis Faktor-Faktoryang Mempengaruhi Pertumbuhan Klaster Batik Pekalongan (Studi Kasus pada Klaster Batik Kauman, Pesindondan Jenggot), J@TI Undip, Vol.VIII, No.1, Hal: 1-14.

14. Tjiptono, Fandy, 2004, Strategi Pemasaran, Edisi 2, Penerbit Andi, Yogyakarta.

15. Undang-Undang Nomor 20 tahun 2008 tentang Usaha Mikro, Kecil dan Menengah, Sekretariat Negara, Jakarta.

16. World Bank, 1994, Infrastructure for Development, diunduh dari: http://documents.worldbank.org/curated/en/6 87361468340136928/World-DevelopmentReport-1994-infrastructure-fordevelopment-executive-summary, diakses pada tanggal27 Desember 2016. 